\title{
Materno-fetal and neonatal outcomes associated with caesarean section delivery in private and public hospitals in low- and middle-income countries: a systematic review
}

\section{Idrissa Beogo ( $\sim$ ibeogo@ustboniface.ca )}

Ecole Nationale de Sante Publique https://orcid.org/0000-0003-1467-2169

\section{Amadou Darboue}

The University of Melbourne School of Population and Global Health

\section{Tiara Marthias}

The University of Melbourne School of Population and Global Health

\section{Sia Drissa}

Universite du Quebec en Outaouais

\section{Tchouaket Nguemeleu Eric}

Universite du Quebec en Outaouais

Julie Savard

Universite de Saint-Boniface

\section{Research}

Keywords: Materno-fetal outcome, caesarean section, private hospitals, public hospitals, low- and middleincome countries, systematic review

Posted Date: March 11th, 2020

DOI: https://doi.org/10.21203/rs.3.rs-16664/v1

License: (c) (i) This work is licensed under a Creative Commons Attribution 4.0 International License. Read Full License 


\section{Abstract}

Background: Advancement in medicine has improved birth assistance. As a result, caesarean section delivery (CSD) has become the most commonly performed surgical procedure. The exponential growth has now skewed toward low- and middle-income countries (LMICs) despite the well-established morbimortality risk and extra costs associated to this procedure. The expansion of private healthcare sector may be playing a significant role. The objective of this review synthesizes knowledge and investigates the difference in materno-fetal and neonatal outcomes of CSD in the perinatal period, between private and public hospitals.

Methods: Medline, Embase, Cinhal, Cochrane Database, LILACS, and HINARI were screened for peerreviewed published studies in English and French, from 1990 to 2019, in human subjects and supplemented by manual searches. The studies included were prospective and retrospective cohort studies, cross-sectional and Delphi studies comparing perinatal outcomes of women whose neonates were delivered by caesarean section and by vaginal delivery in public and private hospitals. In total, the searches yielded 7,762 studies, assessed independently by two assessors. Of these, 26 quantitative studies were included which risk of bias was considered fairly low.

Results: Elective or not, CSD is associated with a variety of outcomes, including death for both the mother and the neonate. Low quality of life, postpartum depression, infections, and scars were burdens attributable to CSD in both sectors. CSD is associated with less urinary incontinence compared to vaginal delivery but no difference exists in early skin-to-skin contact or in early breastfeeding introduction. Finally, across continents, Africa leads in terms of adverse consequences.

Discussion/Conclusion: Private facilities surpassed public ones in CSD rate but were associated with the least severe materno-neonatal outcomes. Countries like China are succeeding through robust policies interventions formulation to contain the CSD epidemic and the health issues associated thereto.

\section{Background}

Caesarean (from caesare in Latin, meaning "to cut") as a delivery method was first documented in 1020 [1]. Since this time, unprecedented improvement has been made, including procedures and incision techniques as well as the discovery of antibiotics, which has definitely increased its safety [2]. This leaves more room for the medicalization of childbirth, putting an end to the then common traditional delivery procedures [3]. Undoubtedly, medically justified CSD (or elective CSD) has been associated with tremendous benefits [4], including the prevention of maternal and perinatal morbidity and mortality [5]. However, as a major surgical procedure, CSD is not risk-free, despite the vigilance of professional and scholarly societies in developing guidelines to maximize its safety [6].

A wealth of studies has reported some morbimortality events associated with CSD. In that line, Gilliam [7] laid out uterine rupture. According to other authors, it may result in major short - or long-term health issues, including greater IgE-mediated sensitization [8], a higher risk of developing asthma [9], neonatal 
lung disease [10], rhinitis or an atopic allergy [11], an increased risk of childhood-onset type 1 diabetes [12], chronic immune disorders [13], celiac disease [14], and modification of the endocrine-immune system in the newborn $[15,16]$. The very recent landmark systematic review of Keag et al. [17] portrayed long-term risks for the mother-infant dyad.

Apart from CSD rates being higher in private hospitals, a differential in materno-fetal and materno-infant outcomes was found between private versus public hospitals $[18,19]$. Some associate this difference to hospital culture [20] or routine [21] even though it does not fit the guideline [6]. Other literature pointed out the supplier-induced demand for profit maximization [22,23], which is likely to be more prevalent in the private health sector. Additionally, the public perception that a CSD is now a nearly risk-free procedure facilitates the request of elective CSD in the absence of clinical indications $[2,22,24,25]$.

To date, CSD prevalence contrasts with the recommendations of the World Health Organization (WHO) of between $10 \%$ and $15 \%$ (WHO, 1985) as the "ideal" rate, suggested since 1985. The mounting trend was first noticed in high-income countries (HICs) [26,27]. Today, however, regardless of the continent, LMICs have surpassed their high-income counterparts with respect to rates of recorded CSD. For instance, statistics show rates of $43.4 \%$ in Colombia, $56.4 \%$ in Dominican Republic, $51.8 \%$ in Egypt, $47.9 \%$ in Iran [28,29], $64.1 \%$ in urban China [30], and $55.6 \%$ in Brazil, where second deliveries by CSD verge on $80 \%$ when the first was by CSD and over $99 \%$ for third births, when the first two were by CSD [28,31].

A wealth of reviews has addressed the subject of CSD from various angles. However, despite the topicality of the challenge, the subsequent materno-fetal and materno-infant outcomes of the procedure from the perspective of hospital ownership (public versus private) still remain unclear. Thus, a systematic review may be necessary to gather and assess current global evidence on materno-fetal and maternoinfant outcomes associated with CSD in public and private hospitals in LMICs. This may be particularly imperative giving the expansion of the private healthcare sector in LMICs in the last two decades. Additionally, such a review could generate information for researchers and policymakers alike allowing for evidence-based decision-making. To do so, this review aims to investigate the difference in maternofetal and neonatal outcomes of CSD in the perinatal period, between private and public hospitals. The review focuses on LMICs with more or less comparable healthcare systems.

\section{Methods}

This review is shaped from the published protocol [32], which was registered within the International Prospective Register of Systematic Reviews (PROSPERO 2016: CRD42016036871). The Cochrane Handbook for Systematic Reviews of Interventions [33] was used as a foundation to carry out this systematic review.

\section{Types of Studies Included and Inclusion Criteria}


This review included quantitative studies as well as qualitative and mixed-method studies. Searches included experimental study design, namely Randomized control trials (RCTs), non-RCTs, before - andafter quasi-experimental and interrupted time series designs. Non-RCT studies included case-control, cohort and cross-sectional studies dealing with CSD. We selected studies that include medicallyprescribed planned and unplanned CSDs performed in accredited public or private healthcare settings, as well as elective CSDs. In addition, primiparous as well as multiparous, twin, and breech births were also included. However, we excluded: 1) utilization of experimental CSDs, 2) stillbirth CSDs, 3) outreach mass surgery, and 4) long-term perinatal outcomes. Countries are listed as LMICs based on the World Bank 2016 country classification [34].

\section{Search Strategy}

The present systematic review adhered to the Preferred Reporting Items for Systematic Reviews and Meta-Analyses (PRISMA) Statement [35]. A concept plan was built and adapted to keywords and descriptors of the six targeted databases. Using a three-step strategy, we first conducted an exploratory search in Ovid-Medline, testing the strategy (descriptors and vocabulary). Second, the strategy was adjusted to each database included. The search strategy was validated by an information specialist (M-C L). Finally, the principal investigator (PI) (IB) performed an extensive and exhaustive search in OvidMedline ${ }^{\circledR}$, CINHAL, Cochrane Database, and Embase. LILACS and HINARI, focusing on low- and middleincome countries, were further screened in December 2018. Grey literature was further examined, including both published and unpublished studies. Finally, additional references were tracked from citations within the pertinent studies. The full search strategy for each database is provided in supplementary 1. Just before the publication draft was issued, IB ran an updated literature search in August 2019. The review considered January 1,1990, as the starting point to coincide with the adoption of WHO's 1985 recommendation [36], leaving a 5-year period as a time lag for countries to implement it. The publication language was restricted to English and French, and all the records imported in the Rayyan reference screening system [37]. IB and AD, independently conducted the initial stream of screening of all titles and abstracts captured to determine eligibility. Using an agreed-upon extraction grid, IB, AD and TM extracted data that was populated in a customized spreadsheet in Microsoft Excel 2010.

\section{Quality Assessment}

We detected bias and graded the quality of studies by employing the Cochrane Risk-of-Bias (ROB) tool for the assessment of possible methodological bias [33]. In order to ensure a consistent overview, crosssectional studies were assessed with the same tool. IB and AD independently rated the quality of each study as either "low", "unclear", or "high" risk of bias, throughout the six domains of the ROB tool (Fig. 3)..

\section{Types of Comparisons}


In the review, we compared the materno-fetal and materno-infant outcomes of CSD in the perinatal period between private and public facilities. For the purpose of this review, private providers were defined as "all organizations and individuals working outside the direct control of the state" [38]. They consist of forprofit (FP) and not-for-profit (NFP) providers; the former are defined as benefit-focused and the latter include philanthropic medical institutions. Institutional stewardship is further considered to complete the definition of the private healthcare sector, because in LMICs, services delivered in the private sector may be publicly financed - in the case of NFP providers [39]. Further, a comparison between continents was conducted.

\section{Outcome Measurement}

Based on the targeted outcomes (materno-fetal and materno-infant), the review looks at the key characteristics that may determine the CSD outcomes: (1) the what (i.e. ownership, financing system, payment scheme, and the management system), the where (2) (country and continent), and (2) the who (i.e. practitioner characteristics). The primary outcomes of interest consisted of perinatal materno-fetal and materno-infant medical outcomes: (1) mortality, (2) morbidity, and (3) observed complications. The secondary outcomes of interest included (1) participants' location; (2) the type of CSD; and (3) other outcomes: birth goal attainment, quality of life, self-efficacy, and social functioning.

\section{Data Analysis and Synthesis}

As expected, no RCT design was met. Furthermore, the interventions in the review were too heterogeneous to pool quantitative data for a meta-analysis. Therefore, we performed a descriptive synthesis, in a narrative form [40].

\section{Results}

\section{Search Results}

Figure 1 exhibits the study selection process using the PRISMA flow diagram. The initial search in August 2018 led to a total of 7,762 potentially relevant citations. Following further screenings, 54 plain texts were reviewed - three from hand-search [41-43] - of which 26 articles were ultimately included in the review (Table 1). In terms of ownership, 14 included both public and private health facilities, 11 run in public facilities only, and one run in a private facility only (Fig 2). Of these reviewed articles, there were seven from Africa [42-48], seven from Asia [49-55], and 10 from Latin America [4,41,56-63], as well as two cross-continental papers [64,65]. The study contexts were both the private and public sectors (Fig 1). No further study was included upon the up-to-date search in July 2019.

\section{Description and Quality of Evidence Reviewed}


Summary descriptions of the articles selected are presented in Table 2. Of the 26 studies selected, approximately $31 \%(n=8)$ and $38.5 \%(n=10)$ have a prospective or retrospective cohort design with a random component. Additionally, one study had a panel design and seven $(27 \%)$ were cross-sectionally designed. When evaluating the quality of the selected studies, we noticed an important variation in the participants sampled. There was a minimum of 109 participants [63] and a maximum of 610,630 participants [59] for single studies, and 83,439 [48] versus 137,094 participants [46] for multicontinental studies. The multi-country participants were however equal: 277,736 [64] versus 286,565 [65].

\section{Narrative Synthesis of Reviewed Evidence}

\section{Maternal Outcomes Associated with Caesarean Section Delivery}

The evidence reviewed showed that CSD in LMICs is associated with a range of maternal health complications. Considering mental health-related outcomes, one prospective cohort study conducted in private institutions found that $11.2 \%$ of post elective-CSD postpartum depressive symptoms, $5.6 \%$ before and after childbirth and $5.6 \%$ after childbirth [63]. Two studies discussed postpartum-related infection. Rwabizi et al. outlined a prevalence of $83 \%$ of maternal morbidity associated with postpartum infection in a sample of public and private facilities [43]. More specifically, Sharma and Dhakal found an incidence of surgical site infections (SSI) of 7.6\% [54].

Likewise, for Chu et al., this was 7.3\% (range 1.7-10.4\%) in the DRC, Burundi and Sierra Leone [42]. For public institutions, the surgical site infection SSI incidence was 23.5\% (95\% diagnosed within the two weeks following discharge) in Del Monte and Neto's study [56]. However, in Nepal, undergoing a CSD in public hospitals led to a significantly lower prevalence of SSI (3.8\%), but the most prevalent was postpartum hemorrhage (30.5\%), followed by injury to the surrounding structure (19.2\%) [49]. Sharma \& Dhakal found greater prevalence in low segment CSD $(53.5 \%$ vs. $39 \% ; \chi 2=9.11, p<0.05)$ [54]. Cisse et al., in their mix of private facilities in Senegal, contended with a CSD-related maternal mortality and morbidity at $3.3 \%$ versus 13.85 (with indication), $2.6 \%$ vs. $3.8 \%$ (discretion), $3.7 \%$ vs. $14.6 \%$ (essential) p $<10^{-8}$ [44]. In a panel study analyzing a time trend CSD (2000 to 2011) at the Muhimbili National Hospital in Dar es Salaam, Tanzania, Litorp et al. found an increase in the maternal mortality ratio from $463 / 100,000$ live births to $650 / 100,000(p=0.031)$ [46]. Lumbiganon et al.'s Asian wide cross-sectional study, which randomly selected 122 private and public facilities, found an important risk associated to CSD [53]. Compared to spontaneous delivery, antepartum CSD with indication was increased (adjusted odds ratio $[\mathrm{aOR}]=1.1,0.5-2.3)$. The risk was even greater during the intrapartum stage: $\mathrm{aOR}=4.8(95 \% \mathrm{Cl}$ $=0.6-36,5)$ (without indication) and $\mathrm{aOR}=1.6(95 \% \mathrm{Cl}=0.9-2.8)$ (with indication) [53].

In dealing with urinary incontinence (UI) in public institutions, Borges et al. [41] found that the burden was borne more by mothers who underwent normal vaginal delivery (VD) for either mixed UI (OR $=8.53,95 \%$ $\mathrm{Cl}=1.25-364.12)$ or stress $\mathrm{UI}(\mathrm{OR}=9.07,95 \% \mathrm{Cl}=1.34-385.56)$ than for CSD: mixed UI (OR $=7.3,95 \%$ $\mathrm{Cl}=0.83-341.94)$ and stress $\mathrm{UI}(\mathrm{OR}=2.43,95 \% \mathrm{Cl}=0.12-146.16)$. Similarly, Kavosi et al. [51] 
highlighted a low postpartum quality of life (QOL) (mental health score, SF-36) for CS delivery (56.05 \pm 11.97$)$ compared to normal VD $(60.17 \pm 18.76)$ and water birth $(61.41 \pm 11.16)$, but the difference was not significant $(p=0.247)$. Silva et al.'s research in aggregating public and private facilities in a cross-sectional study of 2,434 singleton live births found that mothers who underwent CSD (33.7\%) show an increased risk of low birth weight (LBW) $(\mathrm{OR} 1.58,95 \% \mathrm{Cl} 1.09-2.26)$ [61]. One study focused on the incidence of maternal near - miss events during hospitalization for childbirth care. Mixing both public and private providers, it appears that compared to VD, maternal near-miss events associated with elective CSD were significantly $(p<0.001)$ greater $(A O R=2.54,95 \% \mathrm{Cl} 1.67-3.88)$ than those with intrapartum $\operatorname{CSD}(\mathrm{AOR}=1.05,95 \% \mathrm{Cl} 0.54-2.03)[57]$.

\section{Neonatal Outcomes Associated with CSD}

Over the perinatal period, Litorp et al.'s time trend analysis of CSD (2001 to 2011) found an increase in perinatal mortality $(p=0.381)$ and neonatal distress $(p=0.171)$, although not statistically significant [46]. In Senegal, Cisse et al., after following women undergoing a CSD over a one-month period, found that the magnitude of neonatal mortality and morbidity was $14.5 \%$ vs. $8.7 \%$ (with indication), $2.8 \%$ vs. $3.2 \%$ (discretion), and $12.4 \%$ vs. $5.6 \%$ (essential) $\left(p<5 * 10^{-8}\right.$ ) [44]. In one Nepalese study, $94.5 \%$ of the newborns had APGAR score $\geq 6$ at one minute and $97.9 \%$ at five minutes [49]. For breech and other presentations, CSD tended to be very protective for both the fetal (intepartum without indication: $A O R=$ $0.07,95 \% \mathrm{Cl}=0.03-0.1$; intrapartum with indication: $\mathrm{AOR}=0.3,95 \% \mathrm{Cl}=0.2-0.4$ ) and the perinatal period while either antepartum ( $\mathrm{AOR}=0.2,95 \% \mathrm{Cl}=0.1-0.3$ ) or intrapartum (AOR0.3, 0.2-0.4), was associated with improved perinatal outcomes, but also with increased risk of stay in neonatal ICU (2.0, 1.1-3.6); and 2.1, 1.2-3.7, respectively [53]. In Ethiopia, neonate deaths were estimated at $4.49 \%$ for emergency CSD [45] and $8.93 \%$ of perinatal death of the 392 CSD cases in a Kabul maternity hospital [50]. Sharma \& Dhakal found a rather high prevalence of complications (not specified) in newborns through low segment CSD vs. VD $(52,1 \%$ vs. $28.4 \% ; \chi 2=26.12, p<0.05)$ [54]. Torres et al. analyzed deliveries compiled from both public and private providers, including those with the standard care model ("typical" hospitals) and baby-friendly health facilities ("atypical" hospitals) [62].

Torres et al. conducted a national hospital-based cohort and have observed better neonate outcomes for atypical hospitals for early skin-to-skin contact ( $37.7 \%$ vs. $12.8 \%, p=0.000)$; breastfeeding in the first hour after birth $(65.8 \%$ vs. $11.9 \%, p=0.000)$; rooming-in care during hospitalization $(92.2 \%$ vs. $34.7 \%, p=$ $0.000)$; exclusive breastfeeding up until discharge ( $90.3 \%$ vs. $56.5 \%, p=0.000)$, and adverse neonatal outcomes (3.2\% vs. $2.4 \%, p=0.250)$ [62]. Another study that includes both private and public facilities shows a significant delay in initiating breastfeeding for emergency CSD $(a O R 63.85,95 \% \mathrm{Cl}=34.09-$ 119.60) and elective CSD (aOR34.49, 95\% Cl = 19.94-59.66) compared to VD [55].

\section{Comparing Outcomes of Elective CSD to Vaginal Delivery}


Gonzales et al., when analyzing Peru-wide secondary perinatal data (563,668 deliveries) from 2000 to 2010 from 43 public health facilities, found that, compared to VD, there was a fourfold increase in the prevalency of maternal mortality for elective CSD $(\mathrm{OR}=4.45,95 \% \mathrm{Cl}=3.21-6.18)$ and as well as for emergency CSD $(\mathrm{OR}=4.8295 \% \% \mathrm{Cl}=3.44-6.75)$ [58]. This mortality rate was higher in low-level hospitals $(\mathrm{OR}=5.5595 \% \mathrm{Cl}=1.46-21.0)$ than in high-level hospitals $\mathrm{OR}=2.3795 \%(\mathrm{Cl}=1.164 .0) . \mathrm{A}$ multi-country study in seven African countries (Algeria, Angola, DRC, Niger, Nigeria, Uganda, Kenya) contended that high emergency caesarean delivery rates are associated with poor perinatal outcomes (fresh stillbirths: $\beta=5.119, p<0.05)$, severe neonatal morbidity $(\beta=5.224, p<0.05)$, while high elective caesarean rates protect fetuses and neonates (fresh stillbirths: $\beta=-6.775, p<0.05$ ), and neonatal death $(\beta=-6.945, p<0.05)$ [48]. Another study in eight Latin American countries (Argentina, Brazil, Cuba,

Ecuador, Mexico, Nicaragua, Paraguay, Peru) with 97,095 parturients of public and private health facilities showed that elective CSD leads to low risk for severe maternal morbidity and mortality index $(\beta=0.277, p$ $=0.02$ ) compared to intrapartum CSD outcomes $(\beta=0.355, p=0.0001)$ [4]. This was similar for perineal laceration or postpartum fistula $(\beta=(-) 0.016, p=0.2$ vs. $\beta=(-) 0.016, p=0.8)$. For fetal outcomes, the likelihood of death was higher for $\operatorname{CSD}(\beta=0.163, p=0.01)$ compared to intrapartum $\operatorname{CSD}(\beta=0.063, p=$ 0.0001 ), but lower for neonatal death for elective (elective CSD, $\beta=0.010, p=0.9$, vs. intrapartum CSD, $\beta$ $=0.072, p=0.2$.

Several authors have approached the comparison between CSD outcomes and VD postpartum QOL and Quality Adjusted Life Days (QALDs). Thus, Kohler et al. [52] found that the VD group had a higher QOL ( $0-3$ days postpartum: 0.28 vs. $0.57,3-7$ days postpartum: 0.59 vs. $0.81 ; p<0.001)$ and was more likely to report no or slight problems in 4 of 5 health dimensions (mobility, self-care, usual activities, pain or discomfort; $p<0.04)$ during interviews ( $1^{\text {st }}$ and $7^{\text {th }}$ days). Similarly, in Nepal, Sharma and Dhakal [49] found that VD led to fewer complications for mothers compared to CSD (39\%, vs. $53.5 \%)$ and likewise for newborns $(28.4 \%$ vs. $52.1 \%)$.

\section{Intercontinental CSD outcomes comparison}

Bauserman et al. conducted a three-continent study in a mix of public and private facilities (India, Pakistan, Kenya, Zambia, Argentina and Guatemala) [64]. The intercontinental comparison resulted in a lower maternal mortality rate (MMR) in Latin America $(91 / 100,000)$ than in Asia $(178 / 100,000)$ and an MMR of $125 / 100,000$ in Africa. The relative risk (RR) of maternal death at six weeks was lower for CSD $(2.4,95 \% \mathrm{Cl}=1.8-3.2)$ compared to assisted $\mathrm{VD}(3.495 \% \mathrm{Cl}=1.8-6.6)$. In a similar comparative analysis, Souza et al., in dealing with private and public institutions, confirmed the aforementioned differences between continents. In Africa, the outcomes were the worst in all measured dimensions: antepartum CSD without indications: $\mathrm{AOR}=71.29,95 \% \mathrm{Cl}=32.06-158.55, \mathrm{CSD}$ with indications, $\mathrm{AOR}=88.61,95 \% \mathrm{Cl}=$ 74.88-104.86), while this was $2.14,95 \% \mathrm{Cl}=1.04-4.43$ and $8.09,95 \% \mathrm{Cl}=7.12-9.1$, respectively in Asia. In Latin American countries, the findings were the best: $1.94,95 \% \mathrm{Cl}=0.77-4.9$ and $3.04,95 \% \mathrm{Cl}=2.71-$ $3.41[65]$. 


\section{CSD Outcomes in Public vs. Private Facilities}

Studying the LBW-related outcomes and clustering the analysis into private and public university hospitals, Murta et al [60] distinguished, through a multiple logistic regression, that there is a higher risk of LBW among born to women undergoing CSD in private hospitals ( $A O R=2.33,95 \% \mathrm{Cl}=1.19-4.55$ ) than in public ones $(\mathrm{OR}=1.4,95 \% \mathrm{Cl}=0.82$ to 2.4$)$. In one study that targeted maternal mortality associated with facility ownership, undergoing CSD in the public sector was $3.3(95 \% \mathrm{Cl}=2.6-4.3)$ and was associated with a risk of maternal mortality, although the rate was $32.9 \%$ compared to $80.4 \%$ in the private sector [59].

\section{Discussion}

This review lays out four crucial results. Firstly, there is a huge discrepancy between public versus private hospitals in terms of maternal and perinatal morbimortality. Secondly, CSD, including elective ones, can result in maternal and perinatal morbimortality. Thirdly, we found a difference between continents in CSD performance-related outcomes, with African outcomes lagging behind. Finally, the results of vigorous policies revealed ways to critically reduce the CSD upward trend and the worst outcomes associated.

This review laid out the relevance of the facilities' ownership in materno-fetal and neonate CSD-related outcomes. Of the 14 studies targeting both public and private facilities $[4,45,48,52-55,57,59-62,64,65]$, only Murta et al. [60] and Kilsztajn et al. [59] have frontally compared the CSD outcomes between participants in public and private institutions. In the case of the former, private institutions led statistically to fewer LBW babies (OR = 1.4 vs. 2.33), while in Kilsztajn et al.'s study, the likelihood of dying from CSD was 3.3 times higher [59]. This, as evidenced in Latin America, confirms the well-known volume-outcome relationship from a great deal of empirical published works [67].

Nevertheless, cross-comparative findings reveal that private facilities offer significantly better outcomes in terms of CSD-related maternal mortality [59] and public health institutions show worse outcomes of severe morbimortality versus VD $[43,58]$. The comparison features show a similar trend while using the Robinson approach for perinatal mortality, neonatal distress, and maternal mortality ratio $[44,46,50]$, or maternal CSD complications [49]. This is also true for the incidence of SSI [56], emergency caesarean (versus VD), as well as the hospital level [58]. However, VD stands to be protective for urinary tract-related outcomes (compared to CSD) and for postpartum QOL (using SF12) [51].

\section{The Within-Sector Comparison of CSD Outcomes}

There was very little comparative data of relevance to CSD-related outcomes in the private versus public sectors at the within-country level. However, in Brazil, despite the much higher prevalence of CSD in the private sector - up to $90 \%[28,59,62]$, the highest in the world $[68,69]$ - the risk of LBW was almost twofold that of the public sector [60]. In regard to SSI, findings in the public sector are very high (23.5\%) 
compared to $0.7 \%-5.1 \%$ reported in Brazil $[70,71]$, but far less compared to subSahara Africa (SSA) situations (15.6\%) [72].

\section{Even Elective CSD Leads to Maternal and Perinatal Morbi-mortality}

This review underlined that, in all the LMIC settings, emergency CSD protects mothers from death [71]. As for high elective CSD rates, it is protective for fetuses and neonates [48]. Compared to VD, elective CSD resulted in significant odds of mortality in Peru [58], maternal mortality in Africa [48], and depressive symptoms in Brazil [63].

In addition to maternal mortality, elective CSD results infetal death and neonatal death [66]. In all settings, in private and public health institutions, elective CSD leads to a delay in breastfeeding $(O R=10.115)$ in Africa [48] and in the Middle East [55]. In addition to preterm birth and its correlates, LBW is among the salient findings in Brazil, the epidemic setting [61], in both public and private facilities in Brazil - more in private facilities [60].

\section{Intercontinental Comparison of CSD Outcomes}

When comparing continents, irrespective of ownership, the findings of $[57,66]$ showed that Latin America performed better with better maternal outcomes comparing VD to CSD, followed by Asian settings. Africa is lagging behind for both antepartum CSD and intrapartum CSD outcomes [65]. This ranking was however partly demonstrated by Bauserman et al.[64]. Indeed, maternal mortality in Africa - in particular in SSA, which has remained which is indicative of the poor quality of maternal services - progressively declined over the last three decades [73]. We argue that the comparatively high adverse outcome associated with CSD in SSA is associated with vigorous policies, including, for instance, general practitioners, non-MD training [74] or free or the levying of a nominal fee by governments for CSDs $[75,76]$. Unfortunately, some countries like Morocco, rapidly lead to an alarming peak rate [77] necessitating a retaliate plan [78].

\section{Hopeful Results in the Reduction of the CSD Trend: Lessons from China}

China, in particular, is paving the way to address the CSD epidemic. Very recent initiatives have shown CSD rates decline, particularly in supercities, by as much as 30\% between 2008 and 2014 [79]. The literature also indicated that other strategies are feasible. Li et al.'s retrospective cohort study demonstrated that trial of labour after caesarean delivery may be a potential strategy for decreasing the CSD rate [80]. This steady decline of CSD, particularly significant among nulliparous and multiparous births without a uterine scar, which is concomitant with a decline in perinatal mortality from 10.1 per 1,000 births to 7.2 per 1,000 births, is the result of institutional interventions and policy change [81]. While in Brazil, Galvao et al. [82] propose the enforcement of Resolução Normativa 368, in addition to structural 
changes (e.g. on-call schedule and higher compensation for vaginal births in the private sector), Yu et al.'s pre- and post-design (2006-2014) demonstrated that institutional and policy interventions (health education, painless delivery, doula care, and controlling CDMR rates) lead to a quick decline from $20.11 \%$ to $4.30 \%$ in Wenzhou, China [83]. The authors suggest the inclusion of CDMR rates in hospitals' performance assessment matrix [82]. Finally, Torloni et al. the systematic review [84] and others literature [85] contended that, the use of Robinson classification as well as clinical and non-clinical classification in intervention policies [83,86], societal approaches [87], and management interventions (health promotion, practitioner training and tightening of hospital regulations) [83] are possible alternatives.

\section{Conclusion}

Interestingly, this review revealed that high emergency CSD rates, unlike high elective CSD rates, were associated with poor perinatal outcomes, while the risk of neonatal death was lower in facilities with high elective CSD rates and, fortunately, high elective CSD rates reduced the risk of fresh stillbirths. In contrast, neonatal deaths increased with high emergency CSD rates. Increased emergency CSD rates were associated with fresh stillbirths, neonatal deaths, and severe neonatal morbidity. In contrast, increased elective CSD rates were associated with fewer fresh stillbirths and neonatal deaths. Despite the quality of the studies selected, the majority of these targeted both the public and private sectors of health, but did not distinguish the part played by each sector in terms of outcome, leaving room for extrapolation, based on the magnitude of the CSD rate in each sector. Finally, all of the Latin American studies in this review were conducted in Brazil.

This systematic review portraying the evidence on materno-fetal and neonatal outcomes between private and public hospitals outlines the critical question on how best to shape policies to optimize the quality and safety of CSD.

\section{Declarations}

\section{Acknowledgements}

The authors are grateful to Marie-Claude Laferrière, Université Laval, for her support in the concept plan development.

\section{Funding}

The authors did not seek or receive any funding.

\section{Availability of data and materials}

Not applicable. 


\section{Authors' contributions}

IB conceived the study. IB and AD conducted the search strategy, extracted data with MT and drafted the first manuscript. SD, ETN and JS reviewed and rearticulated the literature review and reviewed successive drafts of the manuscript. All authors have read and approved the manuscript.

\section{Competing interests}

The authors declare that they have no competing interests.

\section{Consent for publication}

Not applicable.

\section{Ethics approval and consent to participate}

Not applicable.

\section{References}

1. Khatamee M. Historical perspective "Rostam" is born: how? By Cesarean section (940-1020?). ACOG Clinical Review [Internet]. 2000 [cité 29 janv 2020];5:12. Disponible sur: https://linkinghub.elsevier.com/retrieve/pii/S1085686200000273

2. Berghella V, Baxter JK, Chauhan SP. Evidence-based surgery for cesarean delivery. Am J Obstet Gynecol [Internet]. 2005;193:1607-17. Disponible sur: http://www.ncbi.nlm.nih.gov/pubmed/16260200

3. Cardoso JE, Barbosa RHS. O desencontro entre desejo e realidade: a « indústria » da cesariana entre mulheres de camadas médias no Rio de Janeiro, Brasil. Physis [Internet]. 2012 [cité 29 janv 2020];22:35-52. Disponible sur: http://www.scielo.br/scielo.php?script = sci_arttext\&pid = S0103$73312012000100003 \& \operatorname{lng}=\mathrm{pt} \&$ tlng $=\mathrm{pt}$

4. Villar J, Carroli G, Zavaleta N, Donner A, Wojdyla D, Faundes A, et al. Maternal and neonatal individual risks and benefits associated with caesarean delivery: multicentre prospective study. BMJ [Internet]. 2007;335:1025. Disponible sur: https://www.ncbi.nlm.nih.gov/pubmed/17977819

5. Betrán AP, Ye J, Moller A-B, Zhang J, Gülmezoglu AM, Torloni MR. The Increasing Trend in Caesarean Section Rates: Global, Regional and National Estimates: 1990-2014. Zeeb H, éditeur. PLoS ONE [Internet]. 2016 [cité 29 janv 2020];11:e0148343. Disponible sur: https://dx.plos.org/10.1371/journal.pone.0148343

6. National Institute for Health and Excellence,. Caesarean section: Clinical guideline [Internet]. 2011. Disponible sur: www.nice.org.uk/guidance/cg132 
7. Gilliam M. Cesarean Delivery on Request: Reproductive Consequences. Seminars in Perinatology [Internet]. 2006 [cité 29 janv 2020];30:257-60. Disponible sur: https://linkinghub.elsevier.com/retrieve/pii/S0146000506000966

8. Sánchez-Valverde F, Gil F, Martinez D, Fernandez B, Aznal E, Oscoz M, et al. The impact of caesarean delivery and type of feeding on cow's milk allergy in infants and subsequent development of allergic march in childhood. Allergy [Internet]. 2009 [cité 29 janv 2020];64:884-9. Disponible sur: http://doi.wiley.com/10.1111/j.1398-9995.2008.01931.x

9. Thavagnanam S, Fleming J, Bromley A, Shields MD, Cardwell CR. A meta-analysis of the association between Caesarean section and childhood asthma. Clin Exp Allergy [Internet]. 2008 [cité 29 janv 2020];38:629-33. Disponible sur: http://doi.wiley.com/10.1111/j.1365-2222.2007.02780.x

10. Levine E. Mode of delivery and risk of respiratory diseases in newborns. Obstetrics \& Gynecology [Internet]. 2001 [cité 29 janv 2020];97:439-42. Disponible sur: http://linkinghub.elsevier.com/retrieve/pii/S0029784400011509

11. Eggesb $\varnothing M$, Botten $G$, Stigum $H$, Nafstad $P$, Magnus $P$. Is delivery by cesarean section a risk factor for food allergy? Journal of Allergy and Clinical Immunology [Internet]. 2003 [cité 29 janv 2020];112:420-6. Disponible sur: https://linkinghub.elsevier.com/retrieve/pii/S0091674903015410

12. Cardwell CR, Stene LC, Joner G, Cinek O, Svensson J, Goldacre MJ, et al. Caesarean section is associated with an increased risk of childhood-onset type 1 diabetes mellitus: a meta-analysis of observational studies. Diabetologia [Internet]. 2008 [cité 29 janv 2020];51:726-35. Disponible sur: http://link.springer.com/10.1007/s00125-008-0941-z

13. Sevelsted A, Stokholm J, Bonnelykke K, Bisgaard H. Cesarean Section and Chronic Immune Disorders. PEDIATRICS [Internet]. 2015 [cité 29 janv 2020];135:e92-8. Disponible sur: http://pediatrics.aappublications.org/cgi/doi/10.1542/peds.2014-0596

14. Decker E, Engelmann G, Findeisen A, Gerner P, Laass M, Ney D, et al. Cesarean Delivery Is Associated With Celiac Disease but Not Inflammatory Bowel Disease in Children. PEDIATRICS [Internet]. 2010 [cité 29 janv 2020];125:e1433-40. Disponible sur: http://pediatrics.aappublications.org/cgi/doi/10.1542/peds.2009-2260

15. Cho CE, Norman M. Cesarean section and development of the immune system in the offspring. Am J Obstet Gynecol [Internet]. 2013;208:249-54. Disponible sur: http://www.ncbi.nlm.nih.gov/pubmed/22939691

16. Gasparoni A, Ciardelli L, De Amici D, Castellazzi AM, Autelli M, Bottino R, et al. Effect of general and epidural anaesthesia on thyroid hormones and immunity in neonates. Pediatric Anesthesia [Internet]. 2002 [cité 29 janv 2020];12:59-64. Disponible sur: http://doi.wiley.com/10.1046/j.14609592.2002.00752.x

17. Keag OE, Norman JE, Stock SJ. Long-term risks and benefits associated with cesarean delivery for mother, baby, and subsequent pregnancies: Systematic review and meta-analysis. Myers JE, éditeur. PLoS Med [Internet]. 2018 [cité 29 janv 2020];15:e1002494. Disponible sur: https://dx.plos.org/10.1371/journal.pmed.1002494 
18. Murray SF. Relation between private health insurance and high rates of caesarean section in Chile: qualitative and quantitative study. BMJ. 2000;321:1501-5.

19. Padmadas SS, S. SK, Nair SB, K. R. AK. Caesarean section delivery in Kerala, India: evidence from a National Family Health Survey. Social Science \& Medicine. 2000;51:511-21.

20. Declercq E. Childbirth in Brazil: Challenging an Interventionist Paradigm. BIRTH. 2015;42:1-4.

21. Davis-Floyd R. The technocratic, humanistic, and holistic paradigms of childbirth. International Journal of Gynecology \& Obstetrics [Internet]. 2001 [cité 9 févr 2020];75:S5-23. Disponible sur: http://doi.wiley.com/10.1016/S0020-7292\%2801\%2900510-0

22. Copelli FH da S, Rocha L, Zampieri M de FM, Gregório VRP, Custódio ZA de O. Determinants of women's preference for cesarean section. Texto contexto - enferm [Internet]. 2015 [cité 29 janv 2020];24:336-43. Disponible sur: http://www.scielo.br/scielo.php?script $=$ sci_arttext\&pid $=$ S010407072015000200336\&lng $=$ en\&tlng $=$ en

23. Sufang G. Delivery settings and caesarean section rates in China. Bulletin of the World Health Organization. 2007;85:755-62.

24. Langer A, Villar J. Promoting evidence based practice in maternal care: Would keep the knife away. BMJ. 2002;324:942-5.

25. Mazzoni A, Althabe F, Gutierrez L, Gibbons L, Liu NH, Bonotti AM, et al. Women's preferences and mode of delivery in public and private hospitals: a prospective cohort study. BMC Pregnancy Childbirth [Internet]. 2016;16:34. Disponible sur: http://www.ncbi.nlm.nih.gov/pubmed/26857448

26. Chung SH, Seol HJ, Choi YS, Oh SY, Kim A, Bae CW. Changes in the cesarean section rate in Korea (1982-2012) and a review of the associated factors. J Korean Med Sci [Internet]. 2014;29:1341-52. Disponible sur: http://www.ncbi.nlm.nih.gov/pubmed/25368486

27. Menacker F, Declercq E, Macdorman MF. Cesarean delivery: background, trends, and epidemiology. Semin Perinatol [Internet]. 2006;30:235-41. Disponible sur: http://www.ncbi.nlm.nih.gov/pubmed/17011392

28. Barros F, Vaughan J, Victoria C, Huttly S. Epidemic of caesarean sections in Brazil. The Lancet. 1991;338:167-167.

29. Feng XL, Wang Y, An L, Ronsmans C. Cesarean section in the People's Republic of China: current perspectives. Int J Womens Health [Internet]. 2014;6:59-74. Disponible sur: http://www.ncbi.nlm.nih.gov/pubmed/24470775

30. Feng XL, Xu L, Guo Y, Ronsmans C. Factors influencing rising caesarean section rates in China between 1988 and 2008. Bull World Health Organ [Internet]. 2012;90:30-9, 39A. Disponible sur: http://www.ncbi.nlm.nih.gov/pubmed/22271962

31. WHO. World health statistics 2015. Geneva: World Health Organization; 2015.

32. Beogo I, Mendez Rojas B, Gagnon M-P. Determinants and materno-fetal outcomes related to cesarean section delivery in private and public hospitals in low- and middle-income countries: a systematic review and meta-analysis protocol. Syst Rev [Internet]. 2017 [cité 30 janv 2020];6:5. 
Disponible sur: http://systematicreviewsjournal.biomedcentral.com/articles/10.1186/s13643-0160402-6

33. Higgins J, Green S. Cochrane handbook for systematic reviews of interventions. John Wiley \& Sons.; 2011.

34. World Bank,. World Bank Country and Lending Groups [Internet]. 2016. Disponible sur: https://datahelpdesk.worldbank.org/knowledgebase/articles/906519-world-bank-country-andlending-groups

35. Moher D, Liberati A, Tetzlaff J, Altman DG, Group" "The PRISMA. Preferred Reporting Items for Systematic Reviews and Meta-Analyses: The PRISMA Statement. PLOS Medicine. 2009;6.

36. WHO. WHO Statement on Caesarean Section Rates. Geneva; 2015;1-8.

37. Ouzzani M, Hammady H, Fedorowicz Z, Elmagarmid A. Rayyan-a web and mobile app for systematic reviews. Syst Rev [Internet]. 2016 [cité 30 janv 2020];5:210. Disponible sur: http://systematicreviewsjournal.biomedcentral.com/articles/10.1186/s13643-016-0384-4

38. Bennett S. Promoting the private sector: a review of developing country trends. Health Policy Plan [Internet]. 1992 [cité 30 janv 2020];7:97-110. Disponible sur: https://academic.oup.com/heapol/article-lookup/doi/10.1093/heapol/7.2.97

39. Beogo I, Liu C-Y, Chou Y-J, Chen C-Y, Huang N. Health-Care-Seeking Patterns in the Emerging Private Sector in Burkina Faso: A Population-Based Study of Urban Adult Residents in Ouagadougou. Baradaran HR, éditeur. PLoS ONE [Internet]. 2014 [cité 30 janv 2020];9:e97521. Disponible sur: https://dx.plos.org/10.1371/journal.pone.0097521

40. Zaugg V, Savoldelli V, Sabatier B, Durieux P. Améliorer les pratiques et l'organisation des soins: méthodologie des revues systématiques. Santé Publique [Internet]. 2014 [cité 30 janv 2020];26:655. Disponible sur: http://www.cairn.info/revue-sante-publique-2014-5-page-655.htm

41. Borges JBR, Guarisi T, Camargo ACM de, Gollop TR, Machado RB, Borges PC de G. Urinary incontinence after vaginal delivery or cesarean section. Einstein (São Paulo) [Internet]. 2010 [cité 30 janv 2020];8:192-6. Disponible sur: http://www.scielo.br/scielo.php?script = sci_arttext\&pid = S1679-45082010000200192\&lng = en\&tIng $=$ en

42. Chu K, Maine R, Trelles M. Cesarean Section Surgical Site Infections in Sub-Saharan Africa: A MultiCountry Study from Medecins Sans Frontieres. World J Surg [Internet]. 2015 [cité 30 janv 2020];39:350-5. Disponible sur: http://link.springer.com/10.1007/s00268-014-2840-4

43. Rwabizi D, Rulisa S, Aidan F, Small M. Maternal near miss and mortality due to postpartum infection: a cross-sectional analysis from Rwanda. BMC Pregnancy Childbirth [Internet]. 2016 [cité 30 janv 2020];16:177. Disponible sur: http://bmcpregnancychildbirth.biomedcentral.com/articles/10.1186/s12884-016-0951-7

44. Cisse CT, Faye E, de Bernis L, Dujardin F, Diadhiou F. Césariennes au Sénégal: couverture des besoins et qualité des services. Cahiers d'études et de recherches francophones / Santé. 8(5). 1998;

45. Fesseha N, Getachew A, Hiluf M, Gebrehiwot Y, Bailey P. A national review of cesarean delivery in Ethiopia. International Journal of Gynecology \& Obstetrics [Internet]. 2011 [cité 30 janv 
2020];115:106-11. Disponible sur: http://doi.wiley.com/10.1016/j.ijgo.2011.07.011

46. Litorp H, Kidanto HL, Nystrom L, Darj E, Essén B. Increasing caesarean section rates among low-risk groups: a panel study classifying deliveries according to Robson at a university hospital in Tanzania. BMC Pregnancy Childbirth [Internet]. 2013 [cité 30 janv 2020];13:107. Disponible sur: https://bmcpregnancychildbirth.biomedcentral.com/articles/10.1186/1471-2393-13-107

47. Niyitegeka J, Nshimirimana G, Silverstein A, Odhiambo J, Lin Y, Nkurunziza T, et al. Longer travel time to district hospital worsens neonatal outcomes: a retrospective cross-sectional study of the effect of delays in receiving emergency cesarean section in Rwanda. BMC Pregnancy Childbirth [Internet]. 2017 [cité 30 janv 2020];17:242. Disponible sur: http://bmcpregnancychildbirth.biomedcentral.com/articles/10.1186/s12884-017-1426-1

48. Shah A, Fawole B, M'Imunya JM, Amokrane F, Nafiou I, Wolomby J-J, et al. Cesarean delivery outcomes from the WHO global survey on maternal and perinatal health in Africa. International Journal of Gynecology \& Obstetrics [Internet]. 2009 [cité 30 janv 2020];107:191-7. Disponible sur: http://doi.wiley.com/10.1016/j.ijgo.2009.08.013

49. Dhakal K, Dhakal S, Bhandari S. Profile of Caesarean Section in Mid-Western Regional Hospital in Nepal. J Nepal Health Res Counc. 16(1). 2018;84-8.

50. Kandasamy T, Merialdi M, Guidotti RJ, Betrán AP, Harris-Requejo J, Hakimi F, et al. Cesarean delivery surveillance system at a maternity hospital in Kabul, Afghanistan. International Journal of Gynecology \& Obstetrics [Internet]. 2009 [cité 31 janv 2020];104:14-7. Disponible sur: http://doi.wiley.com/10.1016/j.ijgo.2008.08.024

51. Kavosi Z, Keshtkaran A, Setoodehzadeh F, Kasraeian M, Khammarnia M, Eslahi M. A Comparison of Mothers' Quality of Life after Normal Vaginal, Cesarean, and Water Birth Deliveries. IJCB- NM. 3(3). 2015;198-204.

52. Kohler S, Sidney Annerstedt K, Diwan V, Lindholm L, Randive B, Vora K, et al. Postpartum quality of life in Indian women after vaginal birth and cesarean section: a pilot study using the EQ $-5 D-5 L$ descriptive system. BMC Pregnancy Childbirth [Internet]. 2018 [cité 31 janv 2020];18:427. Disponible sur: https://bmcpregnancychildbirth.biomedcentral.com/articles/10.1186/s12884-018-2038-0

53. Lumbiganon P, Laopaiboon M, Gülmezoglu AM, Souza JP, Taneepanichskul S, Ruyan P, et al. Method of delivery and pregnancy outcomes in Asia: the WHO global survey on maternal and perinatal health 2007-08. The Lancet [Internet]. 2010 [cité 31 janv 2020];375:490-9. Disponible sur: https://linkinghub.elsevier.com/retrieve/pii/S0140673609618705

54. Sharma SR, Dhakal I. Complications among Mothers and New Born Due to Delivery Process in Rupandehi District Nepal. J Nepal Health Res Counc. 16(2). 2018;190-4.

55. Zarshenas M, Zhao Y, Binns CW, Scott JA. Determinants of in-hospital feeding practices in Shiraz, Iran: Results of a prospective cohort study. Birth [Internet]. 2019 [cité 31 janv 2020];46:137-45. Disponible sur: http://doi.wiley.com/10.1111/birt.12385

56. Cardoso Del Monte MC, Pinto Neto AM. Postdischarge surveillance following cesarean section: The incidence of surgical site infection and associated factors. American Journal of Infection Control 
[Internet]. 2010 [cité 29 janv 2020];38:467-72. Disponible sur: https://linkinghub.elsevier.com/retrieve/pii/S0196655310000623

57. Domingues RMSM, Dias MAB, Schilithz AOC, Leal M do C. Factors associated with maternal near miss in childbirth and the postpartum period: findings from the birth in Brazil National Survey, 20112012. Reprod Health [Internet]. 2016 [cité 31 janv 2020];13:115. Disponible sur: http://reproductivehealth-journal.biomedcentral.com/articles/10.1186/s12978-016-0232-y

58. Gonzales GF, Tapia VL, Fort AL, Betran AP. Pregnancy outcomes associated with Cesarean deliveries in Peruvian public health facilities. Int J Womens Health [Internet]. 2013;5:637-45. Disponible sur: http://www.ncbi.nlm.nih.gov/pubmed/24124393

59. Kilsztajn S, Carmo MSN do, Machado LC, Lopes ES, Lima LZ. Caesarean sections and maternal mortality in Sao Paulo. European Journal of Obstetrics \& Gynecology and Reproductive Biology [Internet]. 2007 [cité 31 janv 2020];132:64-9. Disponible sur: https://linkinghub.elsevier.com/retrieve/pii/S0301211506003514

60. Murta EFC, Freire GC, Fabri DC, Fabri RH. Could elective cesarean sections influence the birth weight of full-term infants? Sao Paulo Med J [Internet]. 2006 [cité 31 janv 2020];124:313-5. Disponible sur: http://www.scielo.br/scielo.php?script = sci_arttext\&pid $=$ S1516-31802006000600002\&lng = en\&tlng $=$ en

61. Silva AAM, Lamy-Filho F, Alves MTSSB, Coimbra LC, Bettiol H, Barbieri MA. Risk factors for low birthweight in north-east Brazil: the role of caesarean section. Paediatr Perinat Epidemiol [Internet]. 2001 [cité 31 janv 2020];15:257-64. Disponible sur: http://doi.wiley.com/10.1046/j.13653016.2001.00358.x

62. Torres JA, Domingues RMSM, Sandall J, Hartz Z, Gama SGN da, Filha MMT, et al. Cesariana e resultados neonatais em hospitais privados no Brasil: estudo comparativo de dois diferentes modelos de atenção perinatal. Cadernos de Saúde Pública. 2014;30:S220-31.

63. Zaconeta AM, Queiroz IFB de, Amato AA, Motta LDC da, Casulari LA. Depression with postpartum onset: a prospective cohort study in women undergoing elective cesarean section in Brasilia, Brazil. Rev Bras Ginecol Obstet [Internet]. 2013 [cité 31 janv 2020];35:130-5. Disponible sur: http://www.scielo.br/scielo.php?script = sci_arttext\&pid $=$ S0100-72032013000300007\&lng = en\&nrm = iso\&tlng = en

64. Bauserman M, Lokangaka A, Thorsten V, Tshefu A, Goudar SS, Esamai F, et al. Risk factors for maternal death and trends in maternal mortality in low- and middle-income countries: a prospective longitudinal cohort analysis. Reprod Health [Internet]. 2015 [cité 31 janv 2020];12:S5. Disponible sur: https://reproductive-health-journal.biomedcentral.com/articles/10.1186/1742-4755-12-S2-S5

65. Souza J, Gülmezoglu A, Lumbiganon P, Laopaiboon M, Carroli G, Fawole B, et al. Caesarean section without medical indications is associated with an increased risk of adverse short-term maternal outcomes: the 2004-2008 WHO Global Survey on Maternal and Perinatal Health. BMC Med [Internet]. 2010 [cité 31 janv 2020];8:71. Disponible sur: http://bmcmedicine.biomedcentral.com/articles/10.1186/1741-7015-8-71 
66. Villar J, Valladares E, Wojdyla D, Zavaleta N, Carroli G, Velazco A, et al. Caesarean delivery rates and pregnancy outcomes: the 2005 WHO global survey on maternal and perinatal health in Latin America. The Lancet [Internet]. 2006 [cité 31 janv 2020];367:1819-29. Disponible sur: https://linkinghub.elsevier.com/retrieve/pii/S0140673606687047

67. Morche J, Mathes T, Pieper D. Relationship between surgeon volume and outcomes: a systematic review of systematic reviews. Syst Rev [Internet]. 2016 [cité 31 janv 2020];5:204. Disponible sur: http://systematicreviewsjournal.biomedcentral.com/articles/10.1186/s13643-016-0376-4

68. Locham S, Hussain L, Dakour-Aridi H, Barleben A, Lane J, Malas M. Hospital Volume Impacts the Outcomes of Endovascular Repair of Thoracoabdominal Aortic Aneurysms. Ann Vasc Surg. 2019;

69. Nally DM, Sørensen J, Valentelyte G, Hammond L, McNamara D, Kavanagh DO, et al. Volume and inhospital mortality after emergency abdominal surgery: a national population-based study. BMJ Open [Internet]. 2019 [cité 1 févr 2020];9:e032183. Disponible sur: http://bmjopen.bmj.com/lookup/doi/10.1136/bmjopen-2019-032183

70. Medeiros AC, Aires-Neto T, Azevedo GD, Vilar MJP, Pinheiro LAM, Brandão-Neto J. Surgical site infection in a university hospital in northeast Brazil. Braz J Infect Dis [Internet]. 2005 [cité 1 févr 2020];9:310-4. Disponible sur: http://www.scielo.br/scielo.php?script = sci_arttext\&pid = S1413$86702005000400007 \&$ lng = en\&nrm = iso\&tlng = en

71. Richtmann R, Onzi Siliprandi EM, Rosenthal VD, Sánchez TEG, Moreira M, Rodrigues T, et al. Surgical Site Infection Rates in Four Cities in Brazil: Findings of the International Nosocomial Infection Control Consortium. Surgical Infections [Internet]. 2016 [cité 1 févr 2020];17:53-7. Disponible sur: https://www.liebertpub.com/doi/10.1089/sur.2015.074

72. Sway A, Nthumba P, Solomkin J, Tarchini G, Gibbs R, Ren Y, et al. Burden of surgical site infection following cesarean section in sub-Saharan Africa: a narrative review. IJWH [Internet]. 2019 [cité 1 mars 2020];Volume 11:309-18. Disponible sur: https://www.dovepress.com/burden-of-surgical-siteinfection-following-cesarean-section-in-sub-sa-peer-reviewed-article-lJWH

73. Alkema L, Chou D, Hogan D, Zhang S, Moller A-B, Gemmill A, et al. Global, regional, and national levels and trends in maternal mortality between 1990 and 2015, with scenario-based projections to 2030: a systematic analysis by the UN Maternal Mortality Estimation Inter-Agency Group. The Lancet [Internet]. 2016 [cité 1 févr 2020];387:462-74. Disponible sur: https://linkinghub.elsevier.com/retrieve/pii/S0140673615008387

74. Ouédraogo CM, Ouattara A, Ouédraogo A, Bikienga M, Lankoandé J. Improving the provision of major obstetric interventions by task delegation in Africa: An example from the Bogodogo health district hospital in Ouagadougou, Burkina Faso. Médecine et Santé Tropicales [Internet]. 2015 [cité 1 févr 2020];25:280-4. Disponible sur: http://www.john-libbey-eurotext.fr/medline.md?doi = $10.1684 /$ mst.2015.0451

75. Boukhalfa C, Abouchadi S, Cunden N, Witter S. The free delivery and caesarean policy in Morocco: how much do households still pay? Trop Med Int Health [Internet]. 2016 [cité 1 févr 2020];21:245-52. Disponible sur: http://doi.wiley.com/10.1111/tmi.12638 
76. Ridde V, Yaogo M, Zongo S, Somé P-A, Turcotte-Tremblay A-M. Twelve months of implementation of health care performance-based financing in Burkina Faso: A qualitative multiple case study. Int $\mathrm{J}$ Health Plann Mgmt [Internet]. 2018 [cité 1 févr 2020];33:e153-67. Disponible sur: http://doi.wiley.com/10.1002/hpm.2439

77. Benzouina S, Boubkraoui ME, Mrabet M, Chahid N, Kharbach A, El-hassani A, et al. Fetal outcome in emergency versus elective cesarean sections at Souissi Maternity Hospital, Rabat, Morocco. Pan Afr Med J [Internet]. 2016 [cité 1 févr 2020];23. Disponible sur: http://www.panafrican-medjournal.com/content/article/23/197/full/

78. Zerrour L. La CNOPS resserre l'étau: La césarienne devra désormais être médicalement justifiée [Internet]. 2018. Disponible sur: http://aujourdhui.ma/societe/la-cnops-resserre-letau-la-cesariennedevra-desormais-etre-medicalement-justifiee

79. Li H-T, Luo S, Trasande L, Hellerstein S, Kang C, Li J-X, et al. Geographic Variations and Temporal Trends in Cesarean Delivery Rates in China, 2008-2014. JAMA [Internet]. 2017 [cité 1 févr 2020];317:69. Disponible sur: http://jama.jamanetwork.com/article.aspx?doi = 10.1001/jama.2016.18663

80. Li Y-X, Bai Z, Long D-J, Wang H-B, Wu Y-F, Reilly KH, et al. Predicting the success of vaginal birth after caesarean delivery: a retrospective cohort study in China. BMJ Open [Internet]. 2019 [cité 1 févr 2020];9:e027807. Disponible sur: http://bmjopen.bmj.com/lookup/doi/10.1136/bmjopen-2018027807

81. Liang H, Fan Y, Zhang N, Chongsuvivatwong V, Wang Q, Gong J, et al. Women's cesarean section preferences and influencing factors in relation to China's two-child policy: a cross-sectional study. PPA [Internet]. 2018 [cité 1 févr 2020]; Volume 12:2093-101. Disponible sur: https://www.dovepress.com/womenrsquos-cesarean-section-preferences-and-influencing-factors-inre-peer-reviewed-article-PPA

82. Galvao R, Hawley NL, da Silva CS, Silveira MF. How obstetricians and pregnant women decide mode of birth in light of a recent regulation in Brazil. Women and Birth [Internet]. 2018 [cité 1 févr 2020];31:e310-7. Disponible sur: https://linkinghub.elsevier.com/retrieve/pii/S1871519217303256

83. Yu Y, Zhang X, Sun C, Zhou H, Zhang Q, Chen C. Reducing the rate of cesarean delivery on maternal request through institutional and policy interventions in Wenzhou, China. Räisänen SH, éditeur. PLoS ONE [Internet]. 2017 [cité 1 févr 2020];12:e0186304. Disponible sur: https://dx.plos.org/10.1371/journal.pone.0186304

84. Torloni MR, Betran AP, Souza JP, Widmer M, Allen T, Gulmezoglu M, et al. Classifications for Cesarean Section: A Systematic Review. Althabe F, éditeur. PLoS ONE [Internet]. 2011 [cité 1 févr 2020];6:e14566. Disponible sur: http://dx.plos.org/10.1371/journal.pone.0014566

85. Tura AK, Pijpers O, de Man M, Cleveringa M, Koopmans I, Gure T, et al. Analysis of caesarean sections using Robson 10-group classification system in a university hospital in eastern Ethiopia: a crosssectional study. BMJ Open [Internet]. 2018 [cité 1 févr 2020];8:e020520. Disponible sur: http://bmjopen.bmj.com/lookup/doi/10.1136/bmjopen-2017-020520 
86. Chen I, Opiyo N, Tavender E, Mortazhejri S, Rader T, Petkovic J, et al. Non-clinical interventions for reducing unnecessary caesarean section. Cochrane Effective Practice and Organisation of Care Group, éditeur. Cochrane Database of Systematic Reviews [Internet]. 2018 [cité 1 févr 2020]; Disponible sur: http://doi.wiley.com/10.1002/14651858.CD005528.pub3

87. Wang $E$, Hesketh $T$. Large reductions in cesarean delivery rates in China: a qualitative study on delivery decision-making in the era of the two-child policy. BMC Pregnancy Childbirth [Internet]. 2017 [cité 1 févr 2020];17:405. Disponible sur: https://bmcpregnancychildbirth.biomedcentral.com/articles/10.1186/s12884-017-1597-9

\section{Tables}

Due to technical limitations, full-text HTML conversion of Tables $1 \& 2$ could not be completed. However, they can be downloaded and accessed as a PDF.

\section{Figures}




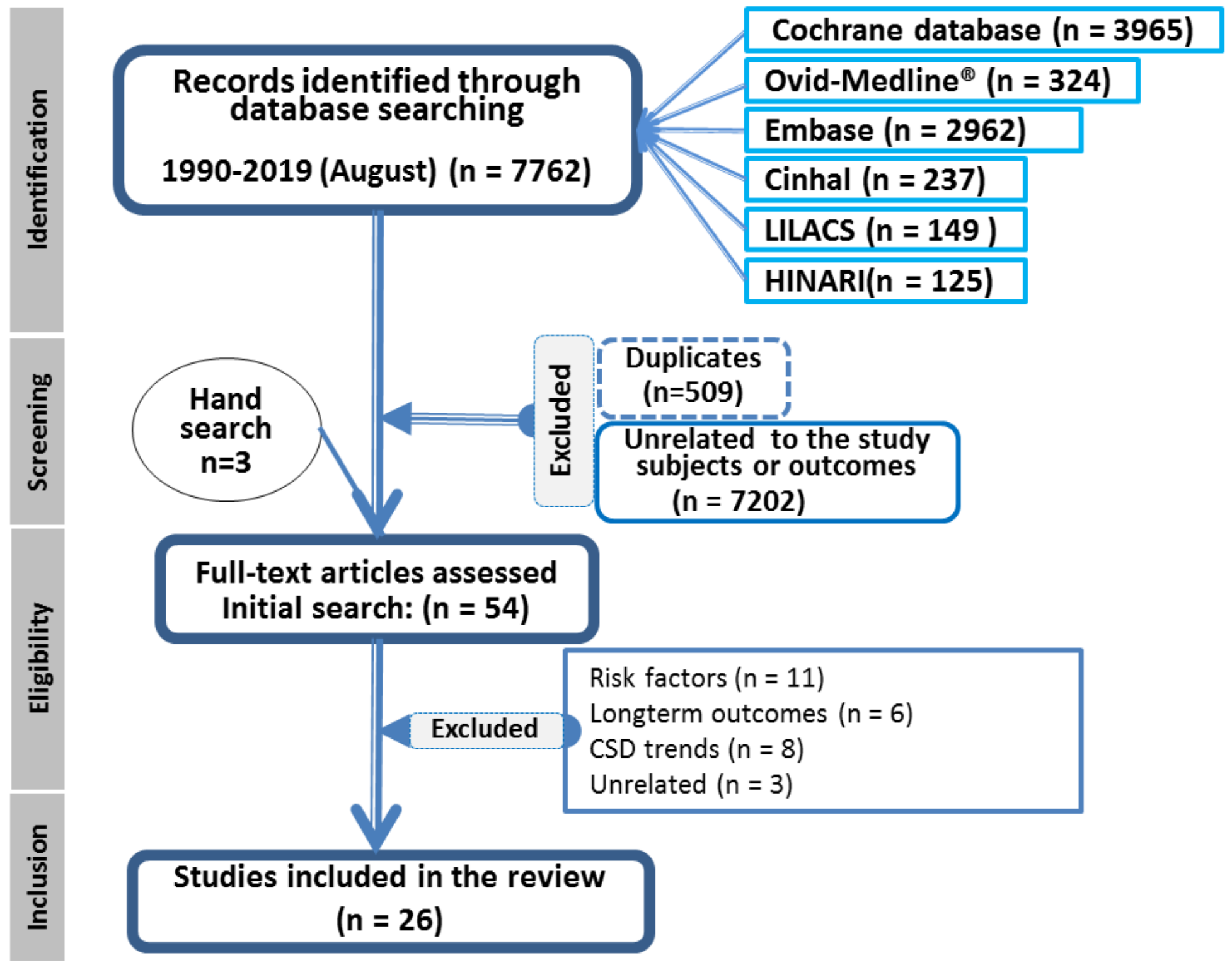

Fig 1. Prisma flow diagram illustrating the search strategy.

Figure 1

Prisma flow diagram illustrating the search strategy 


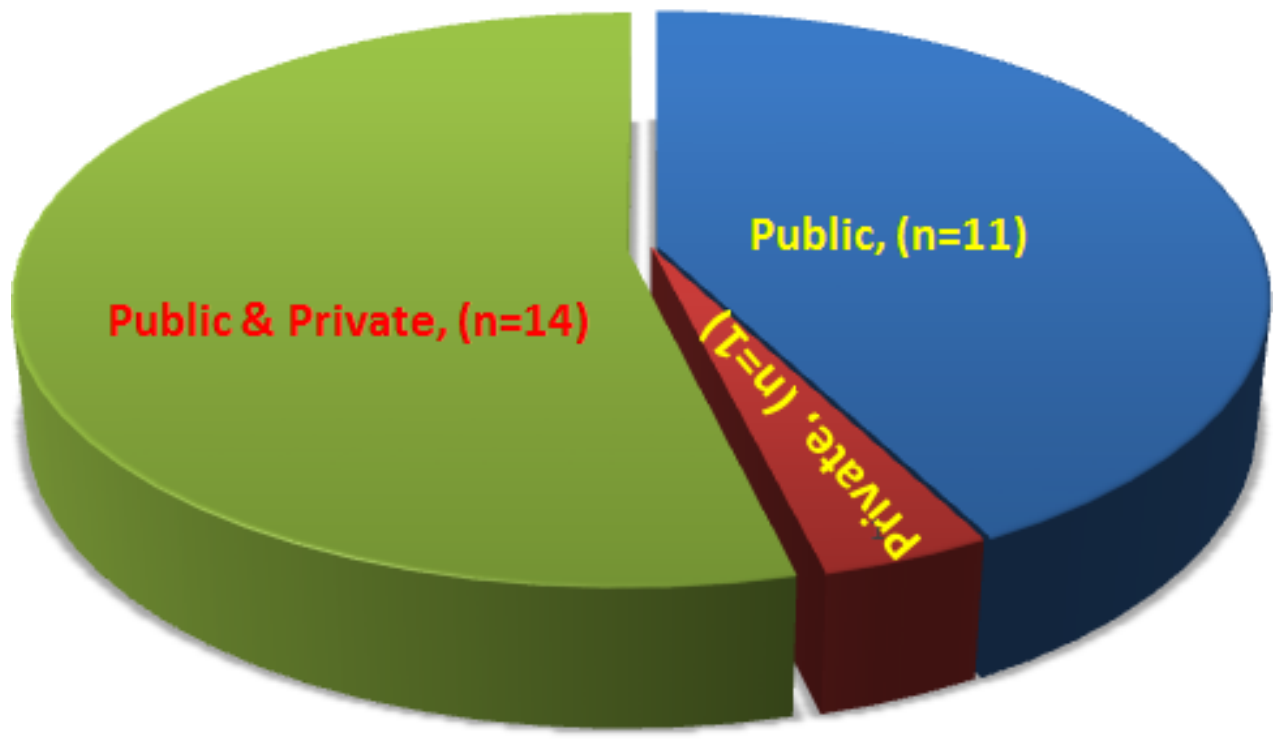

\section{Fig 2: Type of health facility}

Figure 2

Type of health facility 
First author, yr/Bias

Shah et al. 2009

Souza et al. 2010

Rwabizi et al. 2016

Fesseha et al. 2011

Niyitegeka et al. 2017

Litorp et al. 2013

Chu et al. 2015

Dhakal et al. 2018

Kohler et al. 2018

Sharma et Dhakal 2018

Lumbiganon et al. 2010

Gonzales et al. 2013

Bauserman et al. 2015

Borges et al. 2010

Del Monte \& Pinto Neto

Zaconeta et al. 2013

Torres et al. 2014

Domingues et al. 2016

Silva et al. 2011

Murta et al. 2006

Kilsztajn et al. 2007

Villar et al. 2006

Kavosi et al. 2015

Zarshenas et al. 2018

Kandasamy et al. 2009

Cissé et al. 1998
A

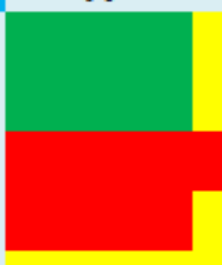

B

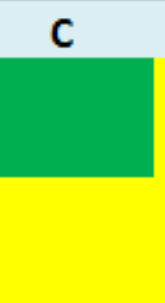

D
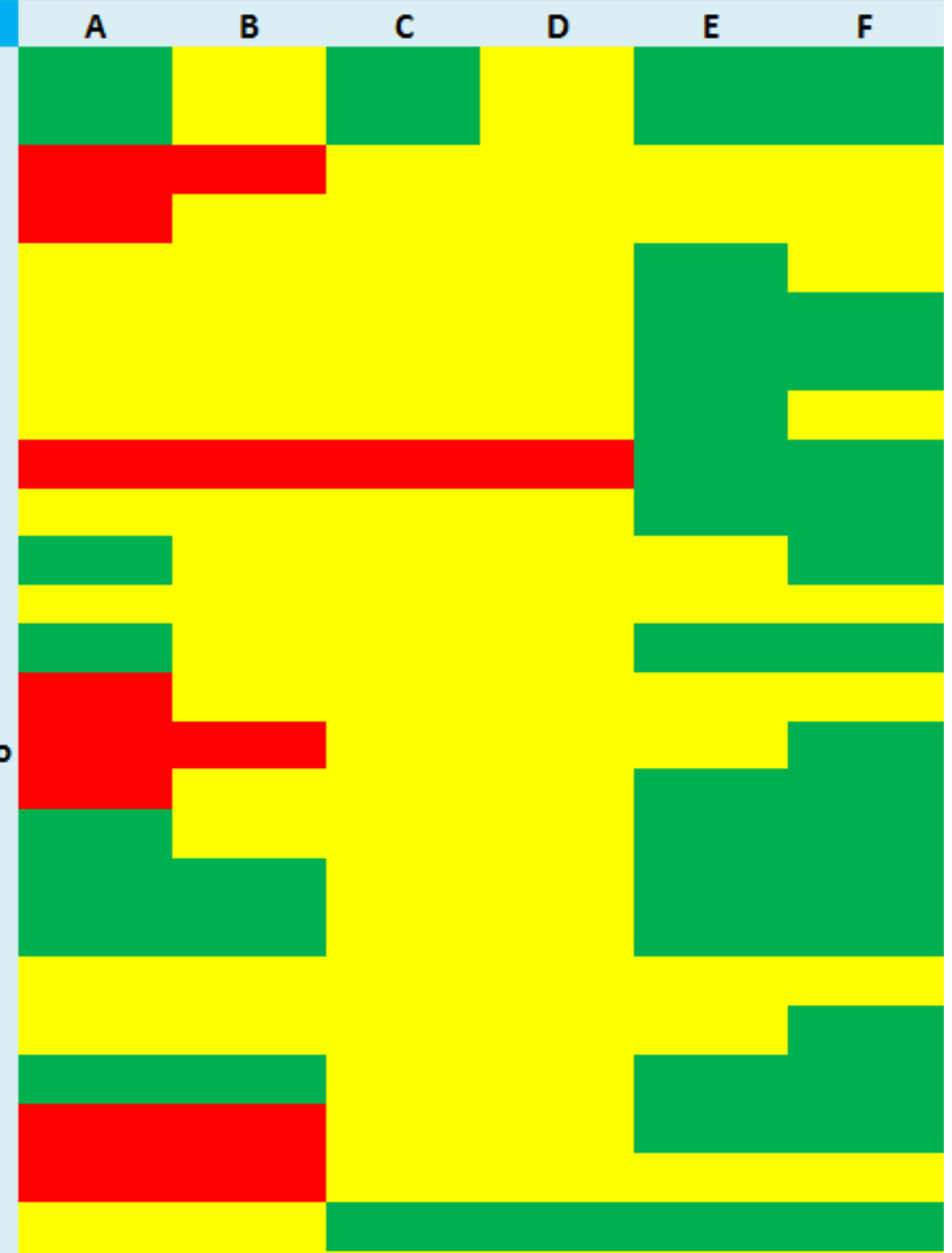

\section{Fig 3: Bias assessment}

\section{Legend:}

\section{Unclear high Low}

A. Sequence generation; B. Allocation concealment

C. Blinding participants; D. Blinding assessors;

E. Selective outcomes; C. Incomplete data outcomes

Figure 3

Bias assessment

\section{Supplementary Files}

This is a list of supplementary files associated with this preprint. Click to download. 
- Supp.File.pdf

- Tables.pdf 